\title{
THE INFLUENCE OF COMMUNITY SERVICE ADVERTISEMENT MINISTRY OF PEOPLE'S HOUSING IN TELEVISION TOWARD COMMUNITY ATTITUDES ABOUT INCREASING OIL FUEL
}

\section{PENGARUH TAYANGAN IKLAN LAYANAN MASYARAKAT KEMENTERIAN PERUMAHAN RAKYAT DI TELEVISI TERHADAP SIKAP MASYARAKAT TENTANG KENAIKAN BAHAN BAKAR MINYAK}

\author{
Angga Mustafa, Vethy Octaviani, Fera Indasari \\ Program Studi IImu Komunikasi Fakultas IImu-IImu Sosial \\ Universitas Dehasen Bengkulu \\ Email: angga.mustapa@yahoo.co.id, vethyoc@gmail.com, fera.mugh4l@unived.ac.id
}

\begin{abstract}
How to Cite :
Octaviani, Vethy. (2020). Pengaruh Tayangan Iklan Layanan Masyarakat Kementerian Perumahan Rakyat Di Televisi Terhadap Sikap Masyarakat Tentang Kenaikan Bahan Bakar Minyak; Sengkuni Journal: Social Sciences and Humanities Vol. 1 No. 22020 page: 1 - 10, DOI: https://doi.org/10.37638/sengkuni.1.2.1-14
\end{abstract}

\section{ARTICLE HISTORY}

Received [xx Month $x x x x]$

Revised [xx Month $x x x x]$

Accepted [xx Month $x x x x]$

\section{KEYWORDS}

Advertising, Kemenpera, Society and BBM (Fuel Oil)

This is an open access article under the $\underline{C C-B Y-S A}$ license

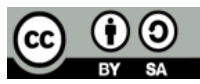

\section{ABSTRAK}

Penelitian ini berjudul pengaruh tayangan iklan layanan masyarakat kementerian perumahan rakyat di televisi terhadap sikap masyarakat tentang kenaikan BBM. Tujuan penelitian ini adalah untuk mengetahui ada tidaknya pengaruh tayangan iklan dengan sikap masyarakat. Penelitian ini mempunyai dua variabel yaitu tayangan iklan layanan masyarakat $(x)$ dan sikap (y). Metode yang digunakan dalam penelitian ini adalah metode kuantitatif, teknik pengumpulan data menggunakan sampel dari suatu populasi dan menggunakan kuesioner sebagai alat pengumpul data yang pokok. Jumlah sampel pada penelitian ini sebanyak 40 orang responden terdiri dari 25 orang laki-laki dengan persentase 62,5\% dan perempuan 15 orang dengan persentase 37,5\%. Dan jika di lihat dari usia di dapatkan responden paling banyak di usia 20-40 tahun dengan persentase $75 \%$. Setelah data diperoleh, hasil penelitian selanjutnya di analisa yang di buktikan dengan uji korelasi pearson (r). Hasil perhitungan yang diperoleh yaitu $r=0,77$ dan thitung $=7,44>t$ tabel $=2,021$. Dari hasil perhitungan tersebut menyatakan adanya pengaruh antara tayangan iklan layanan masyarakat dengan sikap masyarakat.

\section{ABSTRACT}

This study entitled the effect of public service announcements on the Ministry of public housing on television on people's attitudes about the rise in fuel prices. The purpose of this study 
was to determine whether there was an influence of ad
impressions with community attitudes. This research has two
variables, they are public service advertisement (x) and
attitude (y). The method used in this study is a quantitative
method, data collection techniques using samples from a
population and using a questionnaire as a primary data
collection tool. The number of samples in this study were 40
respondents consisting of 25 men with a percentage of $62.5 \%$
and 15 people with a percentage of $37.5 \%$. And if you look at
the age you get the most respondents at the age of $20-40$
years with a percentage of $75 \%$. After the data is obtained, the
results of subsequent studies are analyzed which is proven by
the Pearson correlation test (r). The calculation results
obtained are $r=0.77$ and $t$ arithmetic $=7.44>t$ table $=2.021$.
From the results of these calculations stated there is an
influence between the display of public service ads with the
attitude of the community.

\section{PENDAHULUAN}

Setiap manusia yang hidup di dunia ini, tentu tidak terlepas dari komunikasi yang mereka gunakan sehari-hari untuk berinteraksi terhadap manusia lainnya. Manusia dengan komunikasi hampir tidak dapat dipisahkan satu sama lainya. Secara garis besar komunikasi adalah proses penyampaian pesan/informasi dari komunikator kepada komunikan melalui suatu media kemudian terjadinya feed back (respon/timbal balik). Komunikasi yang baik terjadi apabila antara komunikator dan komunikan mengerti dengan bahasa yang mereka gunakan sehingga meminimalisir terjadinya miss communication/salah pengertian.

Pada dasarnya seluruh aktivitas/kegiatan yang dilakukan oleh manusia selalu menggunakan komunikasi sebagai interaksi unuk melangsungkan aktivitas tersebut. Maka dari itu, komunikasi merupakan suatu kebutuhan yang fundamental (sangat mendasar) bagi kehidupan manusia. Dengan demikian, mengingat sangat pentingnya peran komunikasi dalam kehidupan manusia, komunikasi perlu dipelajari dengan baik karena, komunikasi yang baik dapat digunakan oleh manusia sebagai skil untuk dapat mencari suatu pekerjaan, mencari teman/sahabat, mendapatkan pasangan hidupnya, dan sebagainya. Dengan demikian belajarlah untuk berkomunikasi yang baik dan terampil karena segalanya memerlukan komunikasi.

Pesan iklan sangat penting maka dalam penyampaianya, pengiklan tidak boleh sembarangan dalam membuatnya. Pengiklan harus melakukan riset terlebih dahulu seperti memperhatikan siapa khalayaknya, status sosialnya, kebiasaanya dan sebagainya. Sehingga pengiklan mempunyai informasi yang dapat digunakan dalam membuat strategi penyampaian pesan iklan yang tepat.

Strategi pesan iklan dapat dilakukan dengan dua pendekatan yaitu pesan iklan dengan pendekatan rasional dan pesan iklan emosional. Pesan iklan rasional adalah pesan iklan yang berfokus pada praktek, fungsi, atau kebutuhan konsumen secara optimal terhadap suatu produk, yang memberikan tekanan pada manfaat atau alasan untuk mempunyai atau menggunakan suatu 
merek. Isi pesan menekankan fakta, belajar dan persuasif logis (M. Suyanto. 2004:132).

Sedangkan pesan iklan emosional berhubungan dengan kebutuhan psikologis konsumen untuk membeli suatu produk. Banyak konsumen termotivasi mengambil keputusan dan membeli suatu produk karena emosional dan perasaan terhadap merek dapat menjadi lebih penting daripada pengetahuan terhadap atribut dan pernik-pernik produk tersebut (Ibid.132-134).

Pesan iklan dikatakan berhasil apabila khalayak mengalami perubahan sikap. Menurut Kurt Lewin dalam teori persuasif dalam merancang sebuah program kampanye dalam teori tahapan perubahan menjelaskan bahwa tahapan-tahapan yang dilalui seorang individu dalam rangka mengadopsi sebuah perilaku ada lima tahap yaitu praperenungan (tidak atau belum memiliki kesadaran), perenungan (munculnya kesadaran), persiapan (akibat dari kesadaran sehingga muncul suatu keputusan untuk bertindakan), tindakan (keputusan tersebut dilakukan), pemeliharaan (pesan yang menerpanya membuat melanjutkan atau menguatkan keputusan yang diambil sebelumnya. Jika dihubungkan dengan komponen sikap maka tahap perenungan adalah kognitif (pengetahuan), tahap persiapan adalah afektif (kesukaan), dan tindakan adalah konatif (perilaku).

Pengertian sikap itu sendiri adalah kecenderungan bertindak, berpersepsi, berfikir, dan merasa menghadapi objek, ide, situasi atau nilai, daya pendorong atau motivasi, mengandung nilai menyenangkan atau tidak menyenangkan dan sikap timbul dari pengalaman; tidak dibawa sejak lahir, tetapi merupakan hasil belajar. Karena itu sikap dapat diperteguh atau diubah (Jalaluddin Rakmat. 2008:39-40).

Seperti yang kita ketahui bahwa setiap akan adanya kenaikan Bahan Bakar Minyak (BBM), pro dan kontra selalu bermunculan dalam negeri ini, sebagian beranggapan baik dan sebagian lagi beranggapan buruk bagi perkembangan ekonomi Negara. Dengan banyaknya pro dan kontra yang timbul, berbagai upaya pun dilakukan pemerintah untuk meyakinkan publik bahwa kenaikan BBM bertujuan untuk menerapkan subsidi tepat sasaran, karena selama ini pemerintah beranggapan bahwa subsidi BBM tidak tepat sasaran.Sebagai upaya untuk mempengaruhi publik pemerintah melalui Kementerian Perumahan Rakyat menerbitkan sebuah Iklan layananan Masyarakat berupa dukungan kenaikan BBM oleh Kementerian Perumahan Rakyat.

Iklan Layanan Masyarakat yang diterbitkan oleh Kementerian Perumahan Rakyat mengenai dukungan kenaikan BBM ini ditayangkan melalui media televisi nasional atau televisi pemerintah yaitu TVRI (Televisi Republik Indonesia). Tayangan iklan tersebut menjelaskan bahwa tujuan dari pemerintah ingin menaikkan BBM adalah untuk menerapkan subsidi tepat sasaran, yang mana subsidi yang selama ini diterapkan dianggap kurang tepat dan kurang bermanfaat bagi masyarakat miskin dikarenakan banyaknya golongan ekonomi menengah ke atas juga terlibat menikmati subsidi tersebut.

Upaya pemerintah ingin menaikkan harga BBM didukung secara penuh oleh Kementerian Perumahan Rakyat, dikarenakan Kementerian Perumahan Rakyat mempunyai program ingin menerapkan pengalihan subsidi BBM kepada subsidi perumahan bagi masyarakat miskin. Seperti yang terjadi di 
RW.03 Kelurahan Kebun Beler Kota Bengkulu misalnya, masyarakat RW.03 Kelurahan Kebun Beler Kota Bengkulu, salah seorang waganya telah menerima bantuan dari program pengalihan subsidi BBM tersebut, yang mana kita ketahui bahwa RW.03 Kelurahan Kebun Beler terdiri dari 3 RT yaitu; RT.07, RT.10 RT.12 dan masing-masing RT memiliki jumlah KK (kartu keluarga) sebagai berikut; RT.7 sebanyak $95 \mathrm{KK}, \mathrm{RT} .10$ sebanyak $65 \mathrm{KK}$, dan RT.12 sebanyak $55 \mathrm{KK}$. Dari total keseluruhan KK yang ada di keseluruhan setiap RT maka jumlah KK yang ada di RW.03 Kelurahan Kebun Beler Kota Bengkulu sebanyak 215 KK. Dari 215 KK tersebut hanya satu KK yang mendapatkan bantuan subsidi rumah dari Kementerian Perumahan Rakyat yaitu atas nama Ibu Mislama yang mendapatkan bantuan rumah subsidi oleh program kenaikan BBM dari Kementerian Perumahan Rakyat. Akan tetapi bantuan tersebut masih dalam proses kelengkapan administrasi oleh sang penerima bantuan, yang mana penerima bantuan subsidi rumah tersebut harus menyiapkan segala persyaratan yang diterbitkan oleh Kementerian Perumahan Rakyat itu sendiri seperti; KTP, KK, Surat Keterangan Tidak Mampu dll.Berdasarkan latar belakang diatas maka penulis tertarik mengambil judul "Pengaruh Tayangan Iklan Layanan Masyarakat Kementerian Perumahan Rakyat Di Televisi Terhadap Sikap Masyarakat Tentang Kenaikan BBM"

Adapun tujuan yang ingin dicapai melalui penelitian ini adalah untuk mengetahui Pengaruh Tayangan Iklan Layanan Masyarakat Kementerian Perumahan Rakyat Di Televisi Terhadap Sikap Masyarakat Tentang Kenaikan BBM.

\section{Proses Komunikasi}

\section{LANDASAN TEORI}

Awalnya komunikasi banyak dilakukan dengan cara verbal yaitu ketika manusia belum mengenal tulisan. Tapi semenjak manusia mengenal tulisan, komunikasi dilakukan bukan hanya secara verbal tapi juga dengan non verbal. Dengan komunikasi non verbal, pesan dapat disebarkan secara luas dan dibaca berulang-ulang dengan medium kertas tertentunya.

Pengertian komunikasi menurut Bareslon dan Steiner, adalah proses penyampaian informasi, gagasan, emosi, keahlian dan lain-lain melalui penggunaan simbol-simbol, seperti kata-kata, gambar-gambar, angka-angka dan lain-lain (Sendjaja, S. Djuarsa. 2012 : 1). Sehingga kunci utama dari komunikasi adalah proses penciptaan suatu kesamaan pemikiran yang dikembangkan antara pengirim dan penerima.

Proses komunikasi massa menurut seorang ahli ilmu politik Amerika Serikat bernama Laswell pada tahun 1948 mengemukakan bahwa proses komunikasi massa ini dapat dimengerti dengan menjawab pertanyaan sebagai berikut; "Who says what in which channel to whom with what efek" artinya; siapa, mengatakan apa, dengan media apa, kepada siapa dan efek. Sehingga komunikasi bukan saja sekedar penyampaian pesan melainkan juga dengan tujuan mengubah tingkah laku orang lain yang merupakan efek dari komunikasi. Disini jelas bahwa masalah pengaruh pesan itu merupakan bagian yang penting dalam komunikasi. Akhirnya boleh dikatakan tujuan komunikasi adalah untuk memberikan informasi, mengingatkan dan mempengaruhi khalayak yang dituju. 


\section{Komunikasi Persuasif - Stimulus Respon}

Winston Brembeck dan Wiliam Howelldalam persuasion : A Means Of Social Change (1952), mendefinisikan persuasi sebagai : "usaha sadar untuk mengubah pikiran dan tindakan dengan memanipulasikan motif-motif orang kearah tujuan yang sudah ditetapkan." Pada tahun 1970, kedua profesor komunikasi ini mengubah pendapatnya dengan merumuskan persuasi sebagai: "communication intended to influence choise." (komunikasi yang dimaksudkan untuk mempengaruhi pilihan orang) (Dedy Djamaludin Malik dan Yosal Iriantara. $2013: 14-15)$.

Persuasi bisa dipandang sebagai sebuah cara belajar. Seperti tikus dalam sebuah laboratorium yang bisa belajar mendekati sebagian stimulus dan menampilkan stimulus lainya. Seperti tikus bisa mengubah perilakunya sebagai akibat "pesan-pesan" para pembuat eksperimen, manusiapun bisa mengubah respon yang berkaitan dengan sikap berdasarkan komunikasi persuasif. Teoriteori belajar persuasi sejajar dengan model S-R (Stimulus - Respon ) yang memandang manusia sebagai suatu entitas pasif dari model S-O-R ( StimulusOrganisme-Respons) yang memandang belajar persuasif sebagai suatu gabungan produk pesan yang diterima individu dan mengantari berbagai kekuatan didalam individu yang bertindak berdasarkan pesan-pesan tersebut agar menghasilkan akibat-akibat persuasif (Weiss, 1968). Teori S-R mencoba meramalkan perilaku secara tepat melalui pengetahuan stimuli dan respon yang dapat diamati.

\section{Pesan Iklan}

Pengertian pesan secara sempit adalah apa yang dikatakan atau diimplikasikan oleh sumber melalui kata-kata atau gerak tubuh (gesture) (Rakhmat, Jalaluddin. 2008: 268). Sementara pengertian pesan secara luas adalah segala sesuatu yang dapat berarti bagi penerima(Ruben, Brent. 2010 : 86). Pesan (message) adalah bagian yang penting dalam proses komunikasi periklanan karena melalui pesan, bukan saja informasi yang disampaikan tapi bisa juga mempengaruhi tingkah laku seseorang. Karenanya bentuk pesan yang akan disampaikan harus diperhatikan dan disesuaikan dengan tujuan atau motivasi pesan itu dibuat. Sedangkan pengertian periklanan menurut Wells, Burnett dan Monorty (1998) yaitu advertising is paid non personal communication from an identified sponsor using mass media to persuade or influence an audiens. Yang artinya bahwa periklanan adalah bentuk komunikasi yang dibayar oleh identifikasi sponsor dengan media massa sebagai penyampaian pesan untuk membujuk dan mempengaruhi konsumen yang sifatnya non personal kepada audiens (Sutisna. 2013 : 276).

Menurut Shimp (2003) secara umum, periklanan dihargai karena dikenal sebagai pelaksana beragam fungsi komunikasi yang penting bagi perusahaan bisnis dan organisasi lainnya.

1. Informing (Memberi Informasi), Periklanan membuat konsumen sadar (aware) akan merek-merek baru, mendidik mereka tentang berbagai fitur dan manfaat merek, serta menfasilitasi penciptaan citra merek yang positif.

2. Persuading (Mempersuasi), Iklan yang efektif akan mampu mempersuasi (membujuk) pelanggan untuk mencoba produk dan jasa yang diiklankan. 
3. Reminding (Mengingatkan), Iklan menjaga agar merek perusahaan tetap segar dalam ingatan para konsumen. Saat kebutuhan muncul, yang berhubungan dengan produk yang diiklankan, dampak periklanan di masa lalu memungkinkan merek pengiklan untuk hadir di benak konsumen sebagai kandidat merek yang akan dibeli.

4. Adding Valuememberi nilai tambah pada merk dengan mempengaruhi persepsi konsumen. Iklan berfungsi memberikan nilai tambah bagi perusahaan akan tiga hal yang mendasar, yaitu: terjadinya inovasi, penyempurnaan kualitas, atau perubahan persepsi konsumen.

\section{Iklan Layanan Masyarakat}

Public Service Announcement (iklan layanan masyarakat) merupakan permintaan penyiaran yang dikeluarkan oleh Lembaga Swadaya Masyarakat (LSM) dan pemerintah secara langsung sebagai solidaritas terhadap masalah masyarakat. Contohnya yaitu program pemerintah, ketertiban lalu lintas dan informasi penting lainnya (Kasali. 2014 : 121).

Menurut dewan periklanan di Amerika Serikat yang mensponsori ILM ada beberapa kriteria yang digunakan untuk menentukan sebuah iklan tertentu merupakan iklan layanan masyarakat atau bukan:

1. Tidak komersil (contoh: iklan pemakaian helm dalam berkendara)

2. Tidak bersifat keagamaan.

3. Tidak bersifat politis.

4. Berwawasan nasional

5. Diperuntukkan untuk semua lapisan masyarakat.

6. Diajukan oleh organisasi yang telah diakui dan diterima.

7. Dapat diiklankan.

8. Mempunyai dampak dan kepentingan tinggi sehingga patut memperoleh dukungan media lokal maupun nasional.

\section{Pengertian Sikap}

Sikap adalah konsep yang paling penting dalam psikologi sosial dan yang paling banyak didefinisikan. Ada yang menganggap sikap hanyalah sejenis motif sosiogenis yang diperoleh melalui proses belajar, Sherif dan Sheril dalam Jalaludin Rakhmat (2005). Ada pula yang melihat sikap sebagai kesiapan saraf (neural setting) sebelum memberikan respon. Interpretasi adalah suatu proses untuk menyerderhanakan ide-ide atau isu-isu yang rumit dan kemudian membaginya dengan masyarakat awam/umum. Suatu interpretasi yang baik adalah suatu interpretasi yang dapat membangun hubungan antara audiens dengan obyek interpretasi. Apabila dilakukan secara efektif, interpretasi dapat digunakan untuk meyakinkan seseorang, dapat mendorong seseorang untuk merubah cara berfikir dan tingkah laku seseorang.

Sedangkan menurut Saifudin A (2005) sikap adalah suatu bentuk evaluasi/reaksi terhadap suatu objek, memihak/tidak memihak yang merupakan keteraturan tertentu dalam hal perasaan (afeksi), pemikiran (kognisi) dan predisposisi tindakan (konasi) seseorang terhadap suatu aspek di lingkungan sekitarnya. Menurut Saifudin A (2005), sikap memiliki 3 komponen yaitu :

1. Kognitif, Kognitif terbentuk dari pengetahuan dan informasi yang diterima yang selanjutnya diproses menghasilkan suatu keputusan untuk bertindak. 
2. Afektif, Menyangkut masalah emosional subyektif sosial terhadap suatu obyek, secara umum komponen ini disamakan dengan perasaan yang dimiliki terhadap suatu obyek.

3. Konatif, Menunjukkan bagaimana perilaku atau kecenderungan berperilaku yang ada dalam diri seseorang berkaitan dengan obyek sikap yang dihadapinya.

\section{Kerangka Pemikiran}

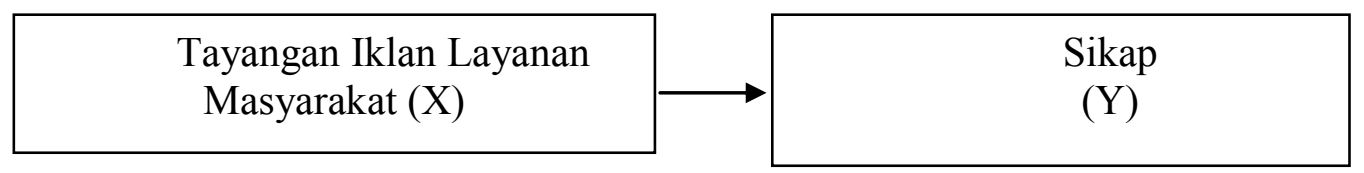

Keterangan :

$\mathrm{X}=$ Variabel Bebas

$\mathrm{Y}=$ Variabel Terikat

\section{Hipotesis}

Hipotesis merupakan jawaban sementara atau proposisi yang akan diuji kebenaranya dan masih memerlukan pembuktian melalui suatu penelitian. Hipotesis harus diuji melalui riset dengan mengumpulkan data yang empiris. Adapun hipotesis pada penelitian ini adalah sebagai berikut :

$\mathrm{Ha}$ : Ada Pengaruh Tayangan Iklan Layanan Masyarakat Kementerian Perumahan Rakyat Di Televisi Terhadap Sikap Masyarakat Tentang Kenaikan BBM.

Ho: Tidak ada Pengaruh Tayangan Iklan Layanan Masyarakat Kementerian Perumahan Rakyat Di Televisi Terhadap Sikap Masyarakat Tentang Kenaikan BBM.

\section{METODE PENELITIAN}

Cara mengumpulkan, mengolah, dan menganalisa data secara kuantitatif (angka-angka) dan secara deskriptif (uraian kalimat) agar dapat memberikan penjelasan dan gambaran yang jelas atas permasalahan yang diteliti, yaitu hubungan iklan layanan masyarakat dengan sikap dukungan masyarakat terhadap kenaikan BBM.

\section{Metode Pengambilan Sampel}

Populasi adalah wilayah generalisasi yang terdiri atas obyek/subyek yang mempunyai kualitas dan karakteristik tertentu yang ditetapkan oleh peneliti untuk dipelajari dan kemudian ditarik kesimpulannya, sedangkan sampel adalah bagian dari jumlah dan karakteristik yang dimiliki oleh populasi tersebut (Sugiyono, 2008). Populasi dalam penelitian ini adalah masyarakat Rw.03 Rt.07 Kelurahan Kebun Beler Kota Bengkulu.

Metode pengambilan sampel pada penelitian ini adalah dengan menggunakan teknikSampling Purposive(penentuan sampel dengan 
pertimbangan tertentu) dan kemudian populasi diambil secara Random Sampling(penarikan sampel secara acak). Menurut Arikunto (2006) apabila populasi lebih dari 100 orang maka sampel diambil $10 \%-15 \%$ atau $20 \%$ sampai $25 \%$ dari populasi. Dalam hal ini sampel yang diambil adalah masyarakat Rw.03 Rt.07 Kelurahan Kebun Beler Kota Bengkulu sebanyak 25\% presisi.

\section{Metode Analisis}

Metode analisis yang digunakan dalam penelitian ini adalah :

1. Analisa kuantitatif; yaitu analisa dengan menggunakan rumus/perhitungan statistik untuk mengetahui Pengaruh Tayangan Iklan Layanan Masyarakat Kementerian Perumahan Rakyat Di Televisi Terhadap Sikap Masyarakat Tentang Kenaikan BBM Pada Masyarakat RW.03 RT.07 Kelurahan Kebun Beler Kota Bengkulu sebagai berikut :

a. Distribusi rata-rata

Untuk mengetahui atau menentukan kategori jawaban responden dari masing-masing variabel apakah tergolong tingkat yang tinggi, sedang, atau rendah maka terlebih dahulu ditentukan skala interval (Sari,2008) dengan cara berikut:

$$
\frac{\text { Skor Tertinggi }- \text { Skor Terendah }}{\text { Banyaknya Bilangan }}
$$

Maka diperoleh $\frac{5-1}{5}=0,80$

Dengan demikian dapat diketahui kategori jawaban responden masingmasing variabel dapat dilihat dengan interval dibawah ini :

$\begin{array}{ll}1,00-1,80 & \text { : Sangat Rendah } \\ 1,81-2,60 & \text { : Rendah } \\ 2,61-3,40 & \text { : Cukup Tinggi } \\ 3,41-4,20 & \text { : Tinggi } \\ 4,21-5,00 & \text { : Sangat Tinggi }\end{array}$

b. Korelasi pearson $r$

Korelasi Pearson $r$ digunakan untuk mengetahui koefisien korelasi hubungan antara dua variabel, jika kedua variabel (variabel independen dan variabel dependen) yang dikorelasikan dinyatakan sebagai data ukuran interval/rasio ialah product-moment-correlation coefficientatau uji pearson $r$. Rumus pearson $r$ yaitu:

$r=\frac{n(\Sigma X Y)-(\Sigma X) \cdot(\Sigma Y)}{\sqrt{n \cdot \Sigma X^{2}-(\Sigma X)^{2}} \cdot \sqrt{n \cdot \Sigma Y^{2}}-(\Sigma Y)^{2}} \quad$ (Silalahi, 2010)

\section{Hasil Penelitian}

\section{HASILDAN PEMBAHASAN}

Berdasarkan penyebaran kuesioner yang dilakukan oleh peneliti di wilayah penelitian RW. 03 Kelurahan Kebun Beler Kota Bengkulu, dapat di lihat hasilnya dari penjelasan di bawah ini: 


\section{Rekapitulasi Hasil Kuesioner Variabel (X) Tayangan Iklan Layanan Masyarakat \\ a. Informing (informasi).}

Sebagian besar yaitu $60 \%$ responden menyatakan bahwa gambar tayangan iklan layanan masyarakat tersebut mampu memberikan informasi pesan iklan dengan baik. Sebagian besar yaitu 55\% responden menyatakan bahwa informasi pada tayangan iklan layanan masyarakat menarik perhatian, karena dikemas dalam bentuk tayangan yang sangat menarik. Sebagian besar responden yaitu $65 \%$ menyatakan bahwa informasi pada tayangan iklan layanan masyarakat mudah di baca dan dimengerti, hal ini menjadi alasan kenapa mereka banyak menyatakan sangat setuju.

b. Persuading (mempersuasi).

Sebagian besar responden yaitu $67,5 \%$ menyatakan bahwa model iklan layanan masyarakat yang diterbitkan oleh kementerian perumahan rakyat menarik perhatian masyarakat. Karena di dalam tayangan iklan tersebut menjelaskan fakta yang terjadi dan memberikan contoh konkret. Sebagian besar responden yaitu $60 \%$ menyatakan bahwa masyarakat merasa iklan yang disampaikan, mampu merubah pola pikir masyarakat, hal ini membuat masyarakat sadar dan mengerti atas apa yang disampaikan oleh iklan tersebutsehingga bisa merubah pola pikir masyarakat. Sebagian responden yaitu $62,5 \%$ menyatakan bahwa tujuan dari iklan sejalan dengan apa yang diharapkan masyarakat, karena di dalam tayangan iklan tersebut memberi nasehat tentang penerapan sebuah keadilan bagi seluruh rakyat indonesia.

\section{c. Reminding (mengingatkan).}

Sebagian besar responden yaitu 65\% menyatakan bahwa iklan layanan masyarakat tentang dukungan kenaikan BBM oleh kementerian perumahan rakyat selalu ditayangkan secara berkala, hal inilah yang membuat masyarakat selalu ingat akan iklan tersebut. Sebagian besar responden yaitu 62,5\% menyatakan bahwa iklan layanan masyarakat tentang dukungan kenaikan BBM oleh kementerian perumahan rakyat, mengingatkan masyarakat bahwa masyarakat bisa membeli rumah subsidi karena hasil dari kenaikkan BBM yang ditawarkan pemerintah. hal ini merupakan daya tarik tersendiri dari iklan yang diterbitkan oleh kementerian perumahan rakyat tersebut. Sebagian besar responden yaitu $57,5 \%$ menyatakan bahwa ; pengucapan bahasa dalam iklan yang diterbitkan oleh kementerian perumahan rakyat, terdengar jelas dan mudah di ingat. Dengan demikan akan lebih mudah untuk mempengaruhi masyarakat banyak.

\section{d. Adding Value (memberi nilai tambah).}

Sebagian besar responden yaitu 65\% menyatakan bahwa iklan layanan masyarakat tersebut memberikan pengetahuan yang mendalam kepada masyarakat, dengan demikian masyarakat bisa memahami dan mengerti tentang tujuan pemerintah untuk menaikkan harga BBM. Dari beberapa tabel diatas dapat disimpulkan kategori jawaban responden untuk variabel tayangan iklan layanan masyarakat $(x)$ sebagai berikut : Dari tabel 13 di atas terlihat rata -rata jawaban responden terhadap variabel tayangan iklan layanan masyarakat $(x)$ sebesar 4,4625 , Nilai tersebut berada di antara interval 4,215,00 (sangat tinggi). Tanggapan responden tertinggi yaitu 4,55 pada 
pernyataan no.1 Informing (informasi) yaitu; (gambar tayangan iklan layanan masyarakat tersebut, mampu memberikan informasi pesan iklan dengan baik) dan no.4 Persuading (mempersuasi) yaitu; (model iklan layanan masyarakat yang diterbitkan oleh kementerian perumahan rakyat, menarik perhatian masyarakat).

\section{Rekapitulasi Hasil Kuesioner Variabel (Y) Sikap \\ a. Kognitif (attention).}

Sebagian responden yaitu $55 \%$ responden menyatakan bahwa pada awal saya melihat iklan dukungan kenaikkan BBM oleh kementerian perumahan rakyat saya menjadi tertarik. Banyak masyarakat tertarik dengan gaya penyampaian dari iklan tersebut.

b. Afektif (interest). Sebagian besar responden yaitu $47,5 \%$ responden menyatakan bahwa setelah melihat tayangan iklan dukungan kenaikkan BBM oleh kementerian perumahan rakyat, saya yakin bahwa saya mengetahui apa yang ingin saya lakukan terhadap iklan itu. Artinya masyarakat tahu apa yang akan dilakukan setelah mereka menonton tayangan iklan tersebut. Sebagian besar responden yaitu $57,5 \%$ responden menyatakan bahwa pertama kali saya melihat iklan dukungan kenaikan BBM oleh kementerian perumahan rakyat, saya percaya bahwa iklan itu mengatakan kebenaran yang saat ini terjadi. Hal ini yang membuat masyarakat siap mendukung kenaikan BBM dikarenakan mereka yakin bahwa ini yang terbaik dilakukan oleh pemerintah. Sebagian besar responden yaitu $62,5 \%$ responden menyatakan isi, gaya, serta penulisan dalam tayangan iklan ini memiliki daya tarik tersendiri bagi saya. Hal inilah yang membuat masyarakat penasaran akan iklan tersebut,sehingga masyarakat ingin menontonnya. Sebagian besar yaitu $57,5 \%$ responden menyatakan bahwa terdapat cerita, gambar atau contoh yang menunjukkan kepada saya bagaimana keutamaan atau manfaat kalau BBM di naikkan. Artinya dalam pernyataan ini dijelaskan bahwa, ketika masyarakat mendukung kenaikan BBM akan menimbulkan efek positif bagi masyarakat itu sendiri.

\section{c. Afektif (desire).}

Sebagian besar yaitu $60 \%$ responden menyatakan bahwa saya sangat senang dengan iklan layanan masyarakat yang diterbitkan oleh kementerian perumahan rakyat, tentang dukungan kenaikkan BBM, sehingga saya bersedia mendukungnya. Dengan daya tarik dan penjelasan yang luar biasa oleh pemerintah melalui iklan layanan masyarakat yang diterbitkan oleh kementerian perumahan rakyat tersebut, maka banyak masyarakat siap untuk mendukungnya.

\section{d. Afektif (decision).}

Sebagian besar yaitu $72,5 \%$ responden menyatakan bahwa saya merasa percaya diri mendukung iklan layanan masyarakat tersebut, karena saya yakin iklan layanan masyarakat tersebut diterbitkan untuk kebaikan rakyat indonesia.dengan diterbitkan iklan tersebut masyarakat banyak memahami tujuan dari kenaikkan BBM itu sendiri, yaitu untuk kebaikan ekonomi secara nasional. Sebagian besar yaitu $65 \%$ responden menyatakan bahwa saya memutuskan dengan sepenuh hati dan jiwa raga untuk mendukung kenaikan BBM. Dengan demikian akan terjadi kemudahan bagi pemerintah untuk 
menaikkan BBM, setelah mendapatkan dukungan secara penuh untuk menaikkan BBM.

\section{e. Konatif (action).}

Sebagian besar yaitu $57,5 \%$ responden menyatakan bahwa saya merasa bangga mendukung iklan layanan masyarakat tersebut, karena saya ikut serta dalam pembangunan perumahan rakyat melalui dukungan terhadap kenaikan BBM. Banyak masyarakat merasa bangga dengan mendukung kenaikan BBM, mereka beranggapan bahwa ketika mereka mendukung itu, maka mereka ikut serta dalam pembangunan bangsa ini. Sebagian besar yaitu 62,5\% responden menyatakan bahwa saya setia dan komitmen dalam mendukung iklan layanan masyarakat tentang kenaikan BBM, yang diterbitkan oleh kementerian perumahan rakyat. Artinya dalam pernyataan ini masyarakat sampai kapanpun tetap berkomitmen mendukung kenaikan BBM selama subsidi BBM yg selama ini dikeluarkan oleh pemerintah, dialihkan ke subsidi perumahan. Dari beberapa tabel diatas dapat disimpulkan kategori jawaban responden untuk variabel sikap (y) sebagai berikut :

a. Di lihat dari tabel. 24 di atasterlihat rata -rata jawaban responden terhadap variabel Sikap (Y) sebesar 4,3625, Nilai tersebut berada di antara interval 4,21-5,00 (sangat tinggi). Tanggapan responden tertinggi adalah 4,475 pada pernyataan no.8 yaitu; saya memutuskan dengan sepenuh hati dan jiwa raga untuk mendukung kenaikan BBM.

b. Dari kedua variabel, yaitu variabel $x$ dan variabel $y$ di atas menunjukkan bahwa tayangan iklan dapat mempengaruhi sikap masyarakat sehingga masyarakat yang sering menonton tayangan iklan dapat mengubah sikap masyarakat, baik sikap positif maupun sikap negatif.

c. Agar dapat mengetahui pengaruh iklan layanan masyarakat variabel $(x)$ dengan sikap masyarakat variabel (y) terhadap dukungan kenaikan BBM oleh kementerian perumahan rakyat, maka digunakan analisis deskriptif kualitatif dan kuantitatif.

d. Berdasarkan perhitungan koefisien korelasi diatas, nilai $r=0,77$ artinya pengaruh antara variabel iklan layanan masyarakat $(x)$ dengan sikap masyarakat (y) adalah positif/kuat, besarnya sumbangan variabel iklan layanan masyarakat (x) dengan variabel sikap (y) sebesar $59 \%$ sedangkan sisanya $41 \%$ di tentukan oleh faktor lain, selain faktor/variabel dalam penelitian ini, Dari hasil hitungan di peroleh $t_{\text {hitung }}>t_{\text {tabel }}(7,44>2,021)$ dengan demikian dapat dinyatakan Ho ditolak dan Ha diterima dapat diartikan bahwa iklan layanan masyarakat kementerian perumahan rakyat mempunyai pengaruh yang signifikan dengan sikap masyarakat Rw.03 Kelurahan Kebun Beler Kota Bengkulu.

\section{Pembahasan}

Berdasarkan hasil penelitian maka dapat disimpulkan bahwa sebagian besar responden yaitu $60 \%$ menyatakan bahwa gambar tayangan iklan layanan masyarakat tersebut mampu memberikan informasi pesan iklan dengan baik, sehingga ketika iklan tersebut di tayangkan mampu menarik perhatian masyarakat banyak sekitar $55 \%$ dari jumlah penonton, dalam iklan tersebut juga dikemas dalam bentuk yang semenarik mungkin, agar masyarakat tertarik 
untuk menontonnya. Selain menarik perhatian iklan tersebut juga terdapat teks yang ditampilkan sehingga $65 \%$ masyarakat yang kurang pendengarannya dapat memahami iklan tersebut dengan membaca teks yang disediakan sehingga membuat banyak orang mengerti akan tujuan iklan tersebut.

Sebagian besar responden yaitu $67,5 \%$ menyatakan bahwa model iklan layanan masyarakat yang diterbitkan oleh kementerian perumahan rakyat menarik perhatian masyarakat, dikarenakan dalam tayangan iklan tersebut menceritakan keadaan serta contoh konkret yang saat ini benar-benar terjadi. Dengan memberikan contoh konkret, harapan pemerintah agar $60 \%$ masyarakat bisa merubah pola pikir yang selama ini tidak setuju dengan kenaikkan harga BBM, pemerintah memiliki harapan agar masyarakat merubah pola pikirnya dari tidak setuju menjadi setuju dan dari tidak mendukung menjadi mendukung secara penuh.

Sebagian besar responden yaitu $62,5 \%$ menyatakan bahwa tujuan dari iklan tersebut sejalan dengan apa yang diharapkan oleh masyarakat, karena didalam iklan tersebut memberikan atau mengajarkan nasehat tentang penerapan sebuah keadilan bagi seluruh rakyat indonesia. Iklan tersebut $65 \%$ selalu ditayangkan secara berkala sehingga membuat masyarakat betul-betul akan selalu di ingatkan dengan nasehat dan ajakan pesan moral yang terdapat dalam iklan tersebut.

Sebagian besar responden yaitu $62,5 \%$ menyatakan bahwa iklan layanan masyarakat tentang dukungan kenaikan BBM oleh kementerian perumahan rakyat, mengingatkan banyak masyarakat bahwa masyarakat bisa membeli rumah subsidi karena hasil dari kenaikan BBM yang ditawarkan oleh pemerintah, artinya dalam hal ini adanya pengalihan subsidi BBM kepada subsidi perumahan bagi masyarakat tidak mampu, hal inilah yang menjadi daya tarik tersendiri bagi iklan tersebut, karena memiliki tawaran yang setimpal atas kebijakan yang dilakukan oleh pemerintah. Tawaran tersebut di ucapkan secara langsung dalam tayangan iklan tersebut yang terdengar jelas dan mudah di ingat oleh masyarakat, sekalipun itu masyarakat awam, artinya; dalam iklan tersebut tidak hanya ingin memberikan pengaruh, akan tetapi lebih kepada memberikan pengetahuan dan pembelajaran terhadap masyarakat agar lebih memahami dan mengerti tentang tujuan pemerintah ingin menaikkan harga BBM tersebut.

Sebagian besar responden yaitu 55\%menyatakan bahwa pada awal mereka melihat tayangan iklan tersebut, mereka langsung tertarik dengan gaya penyampaian dari iklan tersebut, sehingga setelah mereka menonton iklan itu, mereka tahu akan apa yang harus mereka lakukan terhadap penyampaian iklan tersebut, karena mereka memahami betul bahwa iklan tersebut menyampaikan sebuah kebenaran dan kenyataan yang saat ini terjadi. Dengan anggapan itulah akhirnya banyak masyarakat mendukung kenaikkan BBM, karena mereka tahu bahwa tujuan dari kenikkan BBM tersebut memberikan dampak positif kepada masyarakat banyak. Dalam iklan tersebut juga ditampilkan isi, gaya serta penulisan yang cukup menarik, sehingga iklan tersebut memiliki ciri khas tersendiri bagi pendengar dan penikmat dari iklan itu, sehingga banyak masyarakat tidak bosan melihatnya.

Alur cerita serta gambar berupa video yang terdapat dalam iklan tersebut menunjukkan kisah-kisah nyata yang dialami oleh masyarakat miskin yang 
tidak mempunyai rumah dikarenakan tidak mempunyai uang lebih untuk membeli rumah, hal ini dijelaskan secara rincimengapa mereka tidak mampu untuk membeli rumah dikarenakan tingginya atau mahalnya harga rumah, dengan demikian pemerintah melalui kementerian perumahan rakyat menawarkan kepada masyarakat untuk mengalihkan subsidi BBM kepada subsidi perumahan, dengan catatan masyarakat harus mendukung program rumah subsidi dengan menaikkan harga BBM.

Sebagian besar responden yaitu $72,5 \%$ menyatakan bahwa mereka percaya diri, setia, serta bangga dan selalu berkomitmen untuk mendukung kenaikkan BBM yang dilakukan oleh pemerintah sampai kapanpun, dengan catatan pemerintah juga berkomitmen untuk melaksanakan janji yang ditawarkannya kepada masyarakat, selama itu masih dalam konteks kewajaran selama itu pula masyarakat akan tetap mendukung kenaikkan BBM. Tapi tatkala pemerintah mengingkari janjinya dalam memberikan subsidi perumahan, maka dari itu masyarakat akan mencabut dukungan terhadap kenaikkan BBM tersebut

Berdasarkan analisis teori kultivasi bahwasannya teori ini memiliki bentuk paling mendasar yaitu percaya bahwa televisi bertanggung jawab dalam membentuk, atau mendoktrin konsepsi pemirsanya mengenai realitas sosial yang ada disekelilingnya. Media massa menanamkan dan memperkuat ide-ide dan nilai-nilai yang telah terbentuk sebelumnya dalam masyarakat/budaya yang telah terbentuk, media mempertahankan dan menyebarluaskan nilai-nilai tersebut diantara anggota-anggota kebudayaan tersebut, dan mengikatnya menjadi sebuah kesatuan. Hal ini memang terlihat dengan jelas sesuai dengan teori yang dijabarkan diatas bahwasanya media massa mempunyai kekuatan yang cukup besar untuk mempengaruhi pemirsanya, salah satu contoh nyata yang telah terjadi dalam penelitian ini adalah dengan banyaknya pendukung dari kenaikkan BBM yang di lakukan oleh pemerintah. pemerintah memberikan pengaruh kepada masyarakat melalui iklan layanan masyarakat yang dikemas secara baik dan profesional dan dengan data yang akurat, sehingga apa yang disampaikan oleh pemerintah melalui iklan tersebut dapat di dengar dan di patuhi oleh masyarakat banyak. Tidak hanya itu, pemerintah juga meyakinkan pemirsanya dengan menawarkan penawaran yang nyata, seperti mengalihkan subsidi BBM kepada subsidi perumahan, dan ini memang contoh nyata yang dilakukan oleh pemerintah manakala masyarakat mendukung atas kebijakan untuk menaikkan harga BBM tersebut.

\section{KESIMPULAN DAN SARAN}

\section{Kesimpulan}

Dari hasil penelitian di atas maka dapat ditarik kesimpulan sebagai berikut :

1. Dari hasil koefisien korelasi diperoleh nilai untuk korelasi ( $r$ ) sebesar $r=0,77$ berada pada interval kuat yang berarti ada pengaruh yang kuat antara variabel iklan layanan masyarakat $(x)$ terhadap variabel sikap $(y)$.

2. Berdasarkan analisis distribusi rata-rata jawaban responden mengenai variabel iklan layanan masyarakat $(x)$, di lihat dari rata-rata nya adalah sebesar 4,4625 angka tersebut dikatakan sangat tinggi, artinya responden 
mengetahui dengan jelas mengenai iklan layanan masyarakat yang diterbitkan oleh kementerian perumahan rakyat tersebut. Sedangkan untuk rata-rata jawaban responden mengenai variabel sikap (y), di lihat dari ratarata nya adalah sebesar 4,3625 angka tersebut dikatakan sangat tinggi, artinya dengan adanya tayangan iklan layanan masyarakat oleh kementerian perumahan rakyat tersebut maka ada perubahan sikap masyarakat yang ada di Rw.03 Kelurahan Kebun Beler Kota Bengkulu.

3. Berdasarkan uji hipotesis diperoleh nilai $t_{\text {hitung }}$ lebih besar dari $t_{\text {tabel }} . \mathrm{t}$ hitung sebesar 7,44 sedangkan $t$ tabel $2,021(7,44>2,021)$. Ini berarti Ho ditolak dan Ha diterima artinya ada pengaruh yang signifikan antara iklan layanan masyarakat dengan sikap masyarakat Rw.03 Kelurahan Kebun Beler Kota Bengkulu.

\section{Saran}

Dari kesimpulan diatas maka dapat di sarankan sebagai berikut: Melihat dengan antusias nya masyarakat mendukung program kenaikan BBM yang dilakukan pemerintah melalui kementerian perumahan rakyat, dengan kompensasi memberikan subsidi rumah kepada masyarakat yang kurang mampu dari kenaikan BBM tersebut, maka penulis menyarankan agar pemerintah tetap konsisten menjalankan program tersebut, jangan sampai ketika masyarakat telah mendukung secara penuh, tiba-tiba pemerintah menghentikan program kompensasi dari kenaikanBBM tersebut.

\section{DAFTAR PUSTAKA}

Akdon dan Ridwan. 2006. Prosedur Penelitian Suatu Pendekatan Praktik. Jakarta: Rhineka Cipta

Azwar, Saifudin. 2005. Sikap Manusia. Yogyakarta: Pustaka Belajar

Efendy. 1999. IImu Komunikasi Teori dan Praktek. Bandung: Rosdakarya

Jefkins, Frank. 1997. Periklanan. Jakarta: Penerbit Erlangga

Kasali, Rhenald. 1995. Manajemen Periklanan : Konsep dan Aplikasinya di Indonesia. Jakarta: Pustaka Utama Grafiti

Rakhmat, Jalaludin. 2005. Psikologi Komunikasi. Bandung: Remaja Rosdakarya

Rohim, Syaiful. 2009. Teori Komunikasi Perspektif. Jakarta: Rineka Cipta

Satriojati, Wahyu Aji Anindhiyo. 2007. Analisis Perbandingan Efektivitas Iklan Animasi : Studi Pokok Low - Involvement dan High - Involvement. Depok, Universitas Indonesia

Shimp, Terence A. 2003. Periklanan Promosi Aspek Tambahan Komunikasi Pemasaran Terpadu. Jakarta: Erlangga

Singarimbun, Masri dan Sofian Effendi. 1998. Metode Penelitian.

Yogyakarta: LP3ES

Sugiyono. 2008. Metode Penelitian Kuantitatif, Kualitatif dan R\&D. Bandung: Alfabeta 